\title{
Induction of bulb organogenesis in in vitro cultures of tarda tulip (Tulipa tarda Stapf.) from seed-derived explants
}

\author{
Małgorzata Maślanka • Anna Bach
}

Received: 6 February 2013 / Accepted: 22 August 2014 / Published online: 1 October 2014 / Editor: Eric Bunn

(C) The Society for In Vitro Biology 2014. This article is published with open access at Springerlink.com

\begin{abstract}
A protocol for obtaining bulbs via in vitro organogenesis was developed for tarda tulip (Tulipa tarda Stapf). Scale explants were obtained from bulbs formed at the base of seedlings or from adventitious bulbs that developed from callus tissue forming on stolons or on germinating seeds. Some explants were subjected to chilling at $5^{\circ} \mathrm{C}$ for $12 \mathrm{wk}$. The culture media contained 3 or $6 \%$ sucrose and was supplemented with either no growth regulators, either $0.5 \mu \mathrm{M} 6-$ benzyl-aminopurine (BAP) or 18.9 or $94.6 \mu \mathrm{M}$ abscisic acid (ABA). Cultures were maintained in the dark at $20^{\circ} \mathrm{C}$. Callus tissue developed mainly on media without growth regulators or with BAP. Callus was formed from up to $96 \%$ of explants derived from non-chilled adventitious bulbs that were treated with $3 \%$ sucrose and $0.5 \mu \mathrm{M}$ BAP. Less callus was formed from chilled explants compared with non-chilled explants. Newly formed adventitious bulbs appeared on the explants via direct and indirect organogenesis. The media with BAP promoted the formation of adventitious bulbs at a rate of 56$92 \%$ from non-chilled explants, whereas a maximum rate of $36 \%$ was observed from chilled explants. ABA inhibited the induction of adventitious bulbs and callus. The adventitious bulbs obtained in these experiments contained a meristem, which was evidence that they had developed properly.
\end{abstract}

Keywords Tulipa tarda · Bulbing · 6-Benzyl-aminopurine · Abscisic acid

M. Maślanka $(\bowtie) \cdot$ A. Bach

Department of Ornamental Plants, University of Agriculture in

Kraków, Al. 29 Listopada 54, 31-425 Kraków, Poland

e-mail: maslankam@ogr.ar.krakow.pl

\section{Introduction}

Tulips are the most economically important bulbous ornamental plants and have been among the top species produced for cut flowers and bedding for many years (Taghi et al. 2007). Traditionally propagated plants have a long juvenile period of 4-5 yr (Eijk et al. 1991; Rees 1992; Custers et al. 1997), a low reproduction rate, and it takes $25 \mathrm{yr}$ to introduce a new cultivar into production (De Hertogh and Le Nard 1993). The cost of cultivating tulips is therefore high.

Tulipa tarda Stapf. is a member of the botanical tulip group that is a native of Central Asia and is particularly valuable. Due to its low height, a multi-flowered stem (up to six flowers) and the capacity to remain in one place for several years, it is useful for urban green areas unsuitable for other species of tulips (Botschantzeva 1982). The use of biotechnology techniques makes it possible to shorten the time needed to cultivate tulips and to increase their rate of reproduction. However, the laboratory methods for the propagation of tulips remain low yielding (Wilmink et al. 1995; Podwyszyńska and Marasek 2003; Ptak and Bach 2007; Maślanka and Bach 2010). New, more efficient means of in vitro tulip propagation are needed.

In vitro micropropagation of bulbous plants can yield 1,000 descendant bulbs in $1.6 \mathrm{yr}$ from one bulb, which takes about $16 \mathrm{yr}$ under natural conditions (Rees and Hanks 1979). Organogenesis is one method of in vitro plant propagation (Hulscher et al. 1992; Wilmink et al. 1995; Podwyszyńska and Marasek 2003; Ghaffor et al. 2004). Organogenic cultures can be induced from explants obtained from any living part of the plant, including seeds (Niimi 1978; Boeken and Gutterman 1990; Famelaer et al. 2000; Rouhi et al. 2010).

The formation of tulip bulbs is influenced by both chemical and physical characteristics of the culture environment and can be stimulated with appropriate cytokinin treatment, an increased level of sucrose and by chilling the explants. 
Figure 1 Effect of cultivation time, MS concentration and temperature on seed germination.

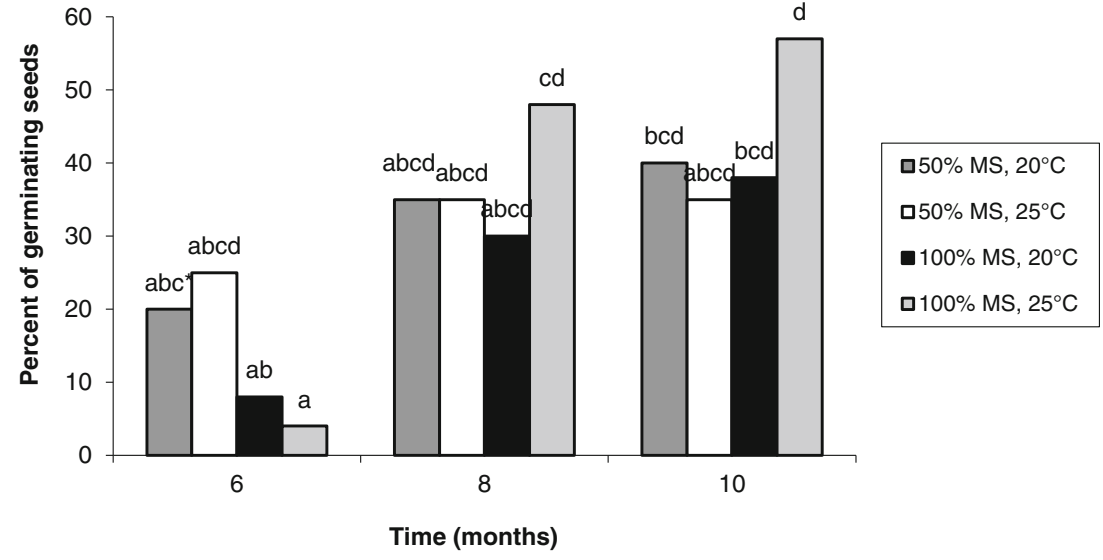

Especially important during in vitro organogenesis or "bulbing" is abscisic acid (ABA), which affects the accumulation of storage proteins and lipids (Seo and Koshiba 2002).

Although conditions suitable for bulb formation in vitro have been preliminarily defined for tulip, this process remains inefficient and unsuitable for obtaining a sufficient number of bulbs in a short time to enable their mass production. In this study, we have focused on tarda tulip in order to develop a more efficient bulbing protocol. The effects of explant chilling, sucrose concentration and 6-benzyl-aminopurine (BAP) and ABA treatments were investigated for their effects on obtaining properly developed adventitious bulbs.

\section{Materials and Methods}

Plant material. Seed germination. T. tarda Stapf. (common name tarda or late tulip) seed was harvested in July, 2009. In October, seeds were surface-disinfected with $70 \%$ ethanol for 1 min followed by immersion in a $15 \%$ solution of Domestos (Unilever, Poland). The seeds were then rinsed three times with sterile water. Disinfected seeds were plated on nutrient media containing either full or half strength (Murashige and Skoog 1962) with 3\% sucrose. All media were solidified with $0.5 \%$ Lab-agar (Biocorp, Poland), and the $\mathrm{pH}$ of all media was adjusted to 5.8 before autoclaving. Each seed was placed individually in a 50-ml glass tube containing 10-ml medium and chilled for $10 \mathrm{wk}$ at $5^{\circ} \mathrm{C}$ in darkness. Cultures were then placed at 20 or $25^{\circ} \mathrm{C}$ under illumination with daylight fluorescent lamps $\left(30 \mu \mathrm{mol} \mathrm{m} \mathrm{m}^{-2} \mathrm{~s}^{-1}\right)$ with a 16 -h photoperiod. Germination was observed 6 mo after the end of the chilling treatment. For the next 4 mo, seed germination characteristics were assessed. Properly germinating seeds developed bulbs on the base of the seedlings, as compared to seeds that formed callus from which many smaller adventitious bulbs developed. All bulbs were used as explants for further experiments.
Induction of callus tissue and adventitious bulbs on scale explants. Scale explants (Fig. 2a, b), consisting of 4-5-mm length pieces of bulbs cut lengthwise, were cultured in Petri dishes $(90 \times 25 \mathrm{~mm})$ on $25-\mathrm{ml}$ MS solid medium $(0.5 \%$ Labagar), containing $0.5 \mu \mathrm{M} \mathrm{BAP}, 18.9$ or $94.6 \mu \mathrm{M} \mathrm{ABA}, 3$ or
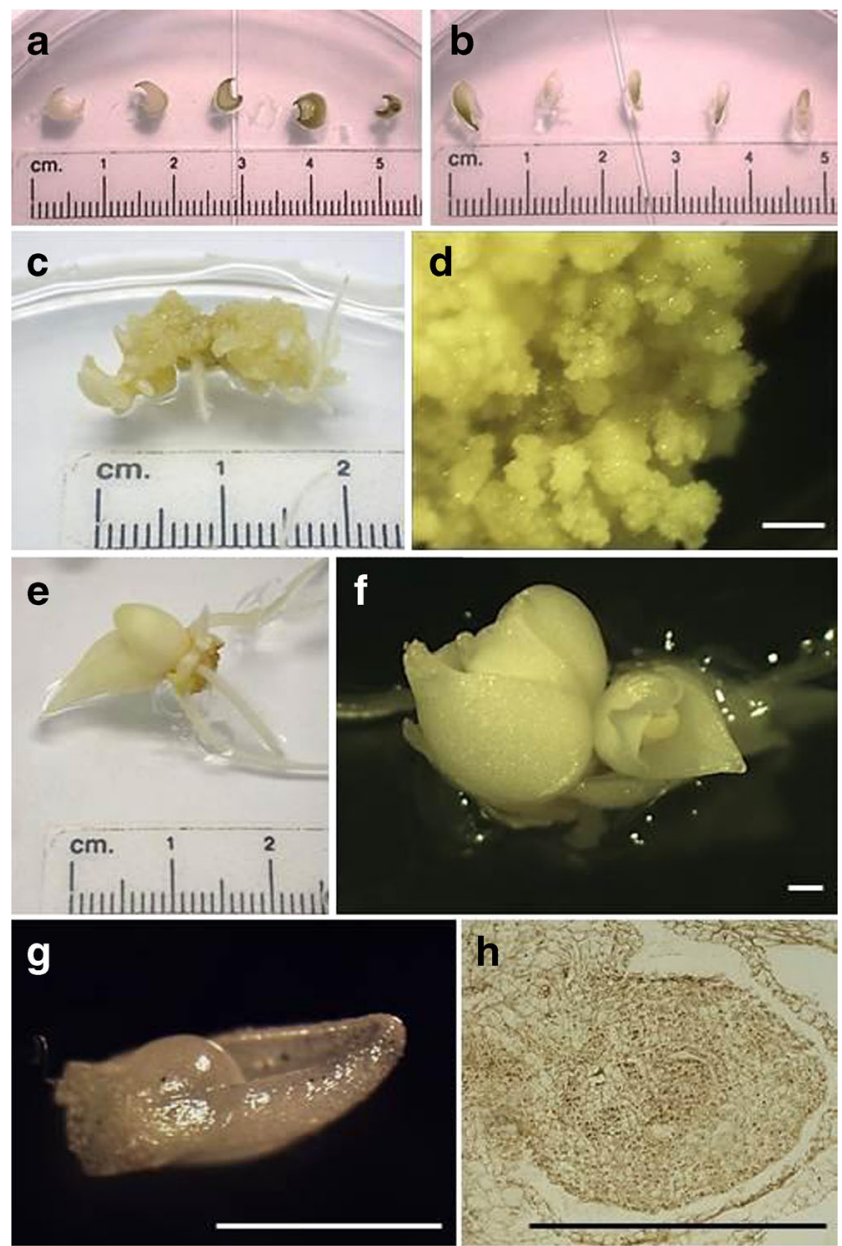

Figure 2 Explant types of T. tarda used ( $a$ ) bulb pieces from seedlings, (b) bulb pieces from adventitious bulbs. Induction of $(c, d)$ callus, $(e, f)$ adventitious bulbs, $(g)$ meristem isolated from adventitious bulb, $(h)$ anatomical cross-section of a bulb. Bars $=1,000 \mu \mathrm{m}$. 
Table 1 Effect of medium composition and time on the induction of callus and bulbs from non-chilled seedling-derived bulbs

\begin{tabular}{|c|c|c|c|c|c|c|c|}
\hline \multirow[t]{2}{*}{ Sucrose $[\%]$} & \multirow[t]{2}{*}{ Growth regulators $[\mu \mathrm{M}]$} & \multicolumn{3}{|c|}{ Explants forming callus [\%] } & \multicolumn{3}{|c|}{ Explants forming bulbs [\%] } \\
\hline & & $4 \mathrm{wk}$ & 8 wk & $12 \mathrm{wk}$ & $4 \mathrm{wk}$ & 8 wk & $12 \mathrm{wk}$ \\
\hline \multirow[t]{4}{*}{3} & - & $0.0 \mathrm{a}^{*}$ & $44.0 \mathrm{bc}$ & $72.0 \mathrm{~d}$ & $56.0 \mathrm{efg}$ & $72.0 \mathrm{efgh}$ & $92.0 \mathrm{~h}$ \\
\hline & $0.5 \mathrm{BAP}$ & $0.0 \mathrm{a}$ & $52.0 \mathrm{~cd}$ & $68.0 \mathrm{~d}$ & $44.0 \mathrm{cdef}$ & $60.0 \mathrm{efg}$ & $72.0 \mathrm{efgh}$ \\
\hline & $18.9 \mathrm{ABA}$ & $0.0 \mathrm{a}$ & $4.0 \mathrm{a}$ & $24.0 \mathrm{ab}$ & $16.0 \mathrm{abcd}$ & $16.0 \mathrm{abcd}$ & $56.0 \mathrm{efg}$ \\
\hline & $94.6 \mathrm{ABA}$ & $0.0 \mathrm{a}$ & $0.0 \mathrm{a}$ & $0.0 \mathrm{a}$ & $0.0 \mathrm{a}$ & $8.0 \mathrm{abc}$ & 32.0 bcde \\
\hline \multirow[t]{4}{*}{6} & - & $0.0 \mathrm{a}$ & $44.0 \mathrm{bc}$ & $56.0 \mathrm{~cd}$ & $48.0 \mathrm{def}$ & $52.0 \mathrm{def}$ & $88.0 \mathrm{gh}$ \\
\hline & $0.5 \mathrm{BAP}$ & $0.0 \mathrm{a}$ & $68.0 \mathrm{~d}$ & $72.0 \mathrm{~d}$ & $56.0 \mathrm{efg}$ & 60.0 efg & $84.0 \mathrm{fgh}$ \\
\hline & $18.9 \mathrm{ABA}$ & $0.0 \mathrm{a}$ & $4.0 \mathrm{a}$ & $20.0 \mathrm{ab}$ & $0.0 \mathrm{a}$ & $4.0 \mathrm{ab}$ & $24.0 \mathrm{abcd}$ \\
\hline & 94.6 ABA & $0.0 \mathrm{a}$ & $0.0 \mathrm{a}$ & $0.0 \mathrm{a}$ & $0.0 \mathrm{a}$ & $0.0 \mathrm{a}$ & $24.0 \mathrm{abcd}$ \\
\hline
\end{tabular}

*Mean values followed by the same letters in columns do not differ at the significance level of $P \leq 0.05$

$6 \%$ sucrose, with a $\mathrm{pH}$ of 5.8 . After 1 wk, explants were transferred to a fresh medium as described above but without ABA. The cultures were maintained in the dark at $20^{\circ} \mathrm{C}$ for 12 wk to allow the formation of adventitious bulbs. Subsequently, the frequencies of the formation of callus tissue and adventitious bulbs (expressed as a percentage) and the number of bulbs per replicate were assessed. The experiment was repeated with explants that had been subjected to chilling at $5^{\circ} \mathrm{C}$ for $12 \mathrm{wk}$.

Dynamics of the adventitious bulbs and callus tissue formation. Undifferentiated callus tissue from non-chilled bulbs was used as the explant in this experiment. Portions of callus $(5 \times 0.2 \mathrm{~g} ; 1 \mathrm{~g}$ total $)$ were transferred to Petri dishes $(90 \times$ $25 \mathrm{~mm}$ ) containing $25-\mathrm{ml}$ media of the same formulation as that on which the callus had formed. The media consisted of MS mineral salts, with either 3 or $6 \%$ sucrose. Half were supplemented also with $0.5 \mu \mathrm{M}$ BAP. All media were adjusted to $\mathrm{pH} 5.8$ and solidified with $0.5 \%$ Lab-agar. The cultures continued to be maintained in the dark at $20^{\circ} \mathrm{C}$. After $12 \mathrm{wk}$, the proliferation of callus, or relative growth rate (RGR= increase in callus weight during the test period/initial weight), the formation of adventitious bulbs (expressed as a percentage), and the number of bulbs per replicate were assessed.

Anatomical observations. Adventitious bulbs were examined using a binocular microscope. Histological studies were carried out on samples imbedded in paraffin after fixation in ethanol/acetic acid (3:1, v/v) (Gerlach 1969). Serial sections were cut to $10 \mu \mathrm{m}$ with a microtome (RM 2145, Leica, Germany) and were stained with safranin and fast green (Jensen 1962).

Statistical analysis. The experiment with seeds was performed with five replicates of 7-8 seeds each. The experiment on the induction and characteristics of bulb formation of bulbs

Table 2 Effect of medium composition and time on the induction of callus and bulbs from chilled seedling-derived bulbs

\begin{tabular}{|c|c|c|c|c|c|c|c|}
\hline \multicolumn{8}{|c|}{ Culture medium } \\
\hline \multirow[t]{2}{*}{ Sucrose $[\%]$} & \multirow[t]{2}{*}{ Growth regulators $[\mu \mathrm{M}]$} & \multicolumn{3}{|c|}{ Explants forming callus [\%] } & \multicolumn{3}{|c|}{ Explants forming bulbs [\%] } \\
\hline & & 4 wk & $8 \mathrm{wk}$ & $12 \mathrm{wk}$ & $4 \mathrm{wk}$ & $8 \mathrm{wk}$ & $12 \mathrm{wk}$ \\
\hline \multirow[t]{4}{*}{3} & - & $0.0 \mathrm{a}^{*}$ & $16.0 \mathrm{abc}$ & $16.0 \mathrm{abc}$ & 20.0 bcde & 20.0 bcde & $28.0 \mathrm{de}$ \\
\hline & $0.5 \mathrm{BAP}$ & $4.0 \mathrm{a}$ & $20.0 \mathrm{abcd}$ & 32.0 cde & $12.0 \mathrm{abcd}$ & 20.0 bcde & $36.0 \mathrm{e}$ \\
\hline & $18.9 \mathrm{ABA}$ & $0.0 \mathrm{a}$ & $0.0 \mathrm{a}$ & $4.0 \mathrm{a}$ & $12.0 \mathrm{abcd}$ & $16.0 \mathrm{abcd}$ & $20.0 \mathrm{bcde}$ \\
\hline & $94.6 \mathrm{ABA}$ & $0.0 \mathrm{a}$ & $0.0 \mathrm{a}$ & $0.0 \mathrm{a}$ & $0.0 \mathrm{a}$ & $0.0 \mathrm{a}$ & $0.0 \mathrm{a}$ \\
\hline \multirow[t]{4}{*}{6} & - & $0.0 \mathrm{a}$ & $20.0 \mathrm{abcd}$ & $40.0 \mathrm{e}$ & $4.0 \mathrm{ab}$ & $4.0 \mathrm{ab}$ & 24.0 cde \\
\hline & $0.5 \mathrm{BAP}$ & $0.0 \mathrm{a}$ & $12.0 \mathrm{ab}$ & $36.0 \mathrm{de}$ & $0.0 \mathrm{a}$ & $12.0 \mathrm{abcd}$ & 24.0 cde \\
\hline & $18.9 \mathrm{ABA}$ & $8.0 \mathrm{ab}$ & $8.0 \mathrm{ab}$ & $8.0 \mathrm{ab}$ & $4.0 \mathrm{ab}$ & $8.0 \mathrm{abc}$ & $12.0 \mathrm{abcd}$ \\
\hline & $94.6 \mathrm{ABA}$ & $0.0 \mathrm{a}$ & $0.0 \mathrm{a}$ & $0.0 \mathrm{a}$ & $0.0 \mathrm{a}$ & $0.0 \mathrm{a}$ & $4.0 \mathrm{ab}$ \\
\hline
\end{tabular}

*Mean values followed by the same letters in columns do not differ at the significance level of $P \leq 0.05$ 
Table 3 Effect of medium composition and time on the induction of callus and bulbs from non-chilled adventitious bulbs

\begin{tabular}{|c|c|c|c|c|c|c|c|}
\hline \multirow[t]{2}{*}{ Sucrose $[\%]$} & \multirow[t]{2}{*}{ Growth regulators $[\mu \mathrm{M}]$} & \multicolumn{3}{|c|}{ Explants forming callus [\%] } & \multicolumn{3}{|c|}{ Explants forming bulbs [\%] } \\
\hline & & $4 \mathrm{wk}$ & 8 wk & $12 \mathrm{wk}$ & $4 \mathrm{wk}$ & $8 \mathrm{wk}$ & $12 \mathrm{wk}$ \\
\hline \multirow[t]{4}{*}{3} & - & $0.0 \mathrm{a}^{*}$ & $52.0 \mathrm{de}$ & $64.0 \mathrm{def}$ & $20.0 \mathrm{ab}$ & $52.0 \mathrm{bcd}$ & $68.0 \mathrm{~d}$ \\
\hline & $0.5 \mathrm{BAP}$ & $8.0 \mathrm{ab}$ & $88.0 \mathrm{f}$ & $96.0 \mathrm{f}$ & $0.0 \mathrm{a}$ & $52.0 \mathrm{bcd}$ & $72.0 \mathrm{~d}$ \\
\hline & $18.9 \mathrm{ABA}$ & $0.0 \mathrm{a}$ & $0.0 \mathrm{a}$ & $0.0 \mathrm{a}$ & $0.0 \mathrm{a}$ & $0.0 \mathrm{a}$ & $0.0 \mathrm{a}$ \\
\hline & $94.6 \mathrm{ABA}$ & $0.0 \mathrm{a}$ & $0.0 \mathrm{a}$ & $8.0 \mathrm{ab}$ & $0.0 \mathrm{a}$ & $0.0 \mathrm{a}$ & $0.0 \mathrm{a}$ \\
\hline \multirow[t]{4}{*}{6} & - & $0.0 \mathrm{a}$ & $16 \mathrm{abc}$ & $40.0 \mathrm{bcd}$ & $20.0 \mathrm{ab}$ & $52.0 \mathrm{bcd}$ & $56.0 \mathrm{~cd}$ \\
\hline & $0.5 \mathrm{BAP}$ & $12.0 \mathrm{abc}$ & $64.0 \mathrm{def}$ & 76.0 ef & $24.0 \mathrm{abc}$ & $64.0 \mathrm{~d}$ & $80.0 \mathrm{~d}$ \\
\hline & $18.9 \mathrm{ABA}$ & $0.0 \mathrm{a}$ & $0.0 \mathrm{a}$ & $0.0 \mathrm{a}$ & $0.0 \mathrm{a}$ & $0.0 \mathrm{a}$ & $0.0 \mathrm{a}$ \\
\hline & $94.6 \mathrm{ABA}$ & $0.0 \mathrm{a}$ & $0.0 \mathrm{a}$ & $0.0 \mathrm{a}$ & $0.0 \mathrm{a}$ & $0.0 \mathrm{a}$ & $0.0 \mathrm{a}$ \\
\hline
\end{tabular}

*Mean values followed by the same letters in columns do not differ at the significance level of $\alpha P \leq 0.05$

was performed with five replicates of five scale explants each. The results were analysed using the two-factorial method of analysis of variance. Comparison of mean values was made with Tukey's test at a significance level of $P \leq 0.05$ using the STATISTICA 9 software package.

\section{Results}

Seed germination. Germination of cultured seeds was observed after 6 mo and continued over a period of 4 mo. Initially, the radicle developed followed by the hypocotyl. Subsequently, the dropper and cotyledon developed, but some seeds formed callus (data not shown). Properly germinating seeds developed a bulb on the seedling base, and many smaller adventitious bulbs developed from the callus.
A higher percentage of germinating seeds was observed on 50 versus $100 \%$ MS medium after 6 mo of culture. After $10 \mathrm{mo}$, the highest germination percentage was observed from seeds cultured on $100 \% \mathrm{MS}$ and $25^{\circ} \mathrm{C}$ (Fig. 1).

Induction of callus tissue and adventitious bulbs on scale explants. Callus tissue that was initially transparent, and which then became yellow, (Fig. $2 c, d$ ) gradually appeared on the explants and was present mainly on explants cultured on medium without growth regulators or medium supplemented with BAP (Tables 1, 2, 3 and 4). After 12 wk, up to $96 \%$ explants derived from adventitious bulbs formed callus when cultures with $3 \%$ sucrose and $0.5 \mu \mathrm{M}$ BAP as compared to other treatments (Table 3). BAP treatment significantly enhanced the frequency of callus induction, but only from nonchilled explants derived from adventitious bulbs, and only on the media containing the $6 \%$ sucrose (Tables 3 and 4 ). Chilled

Table 4 Effect of medium composition and time on the induction of callus and bulbs from chilled adventitious bulbs

\begin{tabular}{|c|c|c|c|c|c|c|c|}
\hline \multicolumn{8}{|c|}{ Culture medium } \\
\hline \multirow[t]{2}{*}{ Sucrose [\%] } & \multirow[t]{2}{*}{ Growth regulators $[\mu \mathrm{M}]$} & \multicolumn{3}{|c|}{ Explants forming callus [\%] } & \multicolumn{3}{|c|}{ Explants forming bulbs [\%] } \\
\hline & & $4 \mathrm{wk}$ & $8 \mathrm{wk}$ & $12 \mathrm{wk}$ & $4 \mathrm{wk}$ & $8 \mathrm{wk}$ & $12 \mathrm{wk}$ \\
\hline \multirow[t]{4}{*}{3} & - & $0.0 \mathrm{a}^{*}$ & $12.0 \mathrm{ab}$ & $32.0 \mathrm{c}$ & $0.0 \mathrm{a}$ & $12.0 \mathrm{ab}$ & $28.0 \mathrm{bc}$ \\
\hline & $0.5 \mathrm{BAP}$ & $0.0 \mathrm{a}$ & $16.0 \mathrm{~b}$ & $38.0 \mathrm{c}$ & $0.0 \mathrm{a}$ & $16.0 \mathrm{abc}$ & $32.0 \mathrm{c}$ \\
\hline & $18.9 \mathrm{ABA}$ & $0.0 \mathrm{a}$ & $0.0 \mathrm{a}$ & $4.0 \mathrm{ab}$ & $0.0 \mathrm{a}$ & $0.0 \mathrm{a}$ & $8.0 \mathrm{a}$ \\
\hline & $94.6 \mathrm{ABA}$ & $0.0 \mathrm{a}$ & $0.0 \mathrm{a}$ & $0.0 \mathrm{a}$ & $0.0 \mathrm{a}$ & $0.0 \mathrm{a}$ & $4.0 \mathrm{a}$ \\
\hline \multirow[t]{4}{*}{6} & - & $0.0 \mathrm{a}$ & $0.0 \mathrm{a}$ & $0.0 \mathrm{a}$ & $8.0 \mathrm{a}$ & $12.0 \mathrm{ab}$ & $12.0 \mathrm{ab}$ \\
\hline & $0.5 \mathrm{BAP}$ & $8.0 \mathrm{ab}$ & $12.0 \mathrm{ab}$ & $32.0 \mathrm{c}$ & $4.0 \mathrm{a}$ & $8.0 \mathrm{a}$ & $18.0 \mathrm{abc}$ \\
\hline & $18.9 \mathrm{ABA}$ & $0.0 \mathrm{a}$ & $4.0 \mathrm{ab}$ & $4.0 \mathrm{ab}$ & $8.0 \mathrm{a}$ & $8.0 \mathrm{a}$ & $8.0 \mathrm{a}$ \\
\hline & $94.6 \mathrm{ABA}$ & $0.0 \mathrm{a}$ & $0.0 \mathrm{a}$ & $0.0 \mathrm{a}$ & $0.0 \mathrm{a}$ & $0.0 \mathrm{a}$ & $0.0 \mathrm{a}$ \\
\hline
\end{tabular}

*Mean values followed by the same letters in columns do not differ at the significance level of $P \leq 0.05$ 
explants (Tables 2 and 4) formed callus to a lesser extent compared to non-chilled explants (Tables 1 and 3).

One week of exposure to ABA, especially at the higher concentration, inhibited the induction of callus, regardless of sucrose concentration and explant type (Tables 1, 2, 3 and 4).

Adventitious bulbs (Fig. 2e, $f$ ) developed on the explants via direct and indirect (via callus) organogenesis within $4 \mathrm{wk}$ of culture. The percentage of explants producing adventitious bulbs increased steadily up to $12 \mathrm{wk}$ of culture. The media containing only sucrose and BAP promoted the formation of adventitious bulb at a frequency of 56-92\% from non-chilled explants (Tables 1 and 3), as compared to a maximum frequency of $36 \%$ from chilled explants (Tables 2 and 4). Short roots were observed at the base of the adventitious bulbs.

ABA had a negative effect on the induction of adventitious bulbs (Tables 1, 2, 3 and 4). This was particularly evident in the case of the explants derived from from non-chilled adventitious bulbs, from which the formation of bulbs was not observed (Table 3 ).

Taking into consideration the effect of the type of explant on the induction of callus, significant differences between means were observed only between the non-chilled and

Table 5 Effect of explant type and medium composition on the induction of callus, adventitious bulbs and the number of these bulbs after 12 wk of cultivation

\begin{tabular}{|c|c|c|c|c|c|}
\hline \multirow[t]{2}{*}{ Explant } & \multicolumn{2}{|c|}{ Culture medium } & \multicolumn{3}{|l|}{ Feature assessed } \\
\hline & $\begin{array}{l}\text { Sucrose } \\
{[\%]}\end{array}$ & $\begin{array}{l}\text { Growth regulators } \\
{[\mu \mathrm{M}]}\end{array}$ & $\begin{array}{l}\text { Explants forming callus } \\
{[\%]}\end{array}$ & $\begin{array}{l}\text { Explants forming bulbs } \\
{[\%]}\end{array}$ & Number of bulbs \\
\hline \multirow[t]{8}{*}{ Non-chilled seedling-derived bulb } & 3 & - & 72.0 def* & $92.0 \mathrm{e}$ & $15.2 \mathrm{def}$ \\
\hline & & $0.5 \mathrm{BAP}$ & $68.0 \mathrm{def}$ & $72.0 \mathrm{de}$ & $16.2 \mathrm{def}$ \\
\hline & & $18.9 \mathrm{ABA}$ & $24.0 \mathrm{abc}$ & 56.0 bcde & $6.0 \mathrm{abcd}$ \\
\hline & & $94.6 \mathrm{ABA}$ & $0.0 \mathrm{a}$ & $32.0 \mathrm{abcd}$ & $1.6 \mathrm{ab}$ \\
\hline & 6 & - & 56.0 bcdef & $88.0 \mathrm{e}$ & $13.2 \mathrm{cdef}$ \\
\hline & & $0.5 \mathrm{BAP}$ & $72.0 \mathrm{def}$ & $84.0 \mathrm{e}$ & $14,2 \mathrm{def}$ \\
\hline & & $18.9 \mathrm{ABA}$ & $20.0 \mathrm{ab}$ & $24.0 \mathrm{ab}$ & $1.6 \mathrm{ab}$ \\
\hline & & $94.6 \mathrm{ABA}$ & $0.0 \mathrm{a}$ & $24.0 \mathrm{ab}$ & $1.2 \mathrm{ab}$ \\
\hline \multirow[t]{8}{*}{ Chilled seedling-derived bulb } & 3 & - & $16.0 \mathrm{ab}$ & $28.0 \mathrm{abc}$ & $5.8 \mathrm{abcd}$ \\
\hline & & $0.5 \mathrm{BAP}$ & $32.0 \mathrm{abcd}$ & $36.0 \mathrm{abcd}$ & $5.8 \mathrm{abcd}$ \\
\hline & & 18.9 ABA & $4.0 \mathrm{a}$ & $20.0 \mathrm{ab}$ & $2.6 \mathrm{abc}$ \\
\hline & & $94.6 \mathrm{ABA}$ & $0.0 \mathrm{a}$ & $0.0 \mathrm{a}$ & $0.0 \mathrm{a}$ \\
\hline & 6 & - & 40.0 abcde & $24.0 \mathrm{ab}$ & $2.6 \mathrm{abc}$ \\
\hline & & $0.5 \mathrm{BAP}$ & 36.0 abcde & $24.0 \mathrm{ab}$ & $2.8 \mathrm{abc}$ \\
\hline & & $18.9 \mathrm{ABA}$ & $8.0 \mathrm{a}$ & $12.0 \mathrm{a}$ & $2.6 \mathrm{abc}$ \\
\hline & & $94.6 \mathrm{ABA}$ & $0.0 \mathrm{a}$ & $4.0 \mathrm{a}$ & $0.2 \mathrm{ab}$ \\
\hline \multirow[t]{8}{*}{ Non-chilled Adventitious bulb } & 3 & - & 64.0 cdef & 68.0 cde & 9.2 abcde \\
\hline & & $0.5 \mathrm{BAP}$ & $96.0 \mathrm{f}$ & $72.0 \mathrm{de}$ & $18.8 \mathrm{ef}$ \\
\hline & & $18.9 \mathrm{ABA}$ & $0.0 \mathrm{a}$ & $0.0 \mathrm{a}$ & $0.0 \mathrm{a}$ \\
\hline & & $94.6 \mathrm{ABA}$ & $8.0 \mathrm{a}$ & $0.0 \mathrm{a}$ & $0.0 \mathrm{a}$ \\
\hline & 6 & - & 40.0 abcde & 56.0 bcde & $13.8 \mathrm{def}$ \\
\hline & & $0.5 \mathrm{BAP}$ & $76.0 \mathrm{ef}$ & $80.0 \mathrm{e}$ & $14.0 \mathrm{def}$ \\
\hline & & 18.9 ABA & $0.0 \mathrm{a}$ & $0.0 \mathrm{a}$ & $0.0 \mathrm{a}$ \\
\hline & & $94.6 \mathrm{ABA}$ & $0.0 \mathrm{a}$ & $0.0 \mathrm{a}$ & $0.0 \mathrm{a}$ \\
\hline \multirow[t]{8}{*}{ Chilled adventitious bulb } & 3 & - & $32.0 \mathrm{abcd}$ & $28.0 \mathrm{abc}$ & 10.8 bcdef \\
\hline & & $0.5 \mathrm{BAP}$ & 38.0 abcde & $32.0 \mathrm{abcd}$ & $6.2 \mathrm{abcd}$ \\
\hline & & $18.9 \mathrm{ABA}$ & $4.0 \mathrm{a}$ & $8.0 \mathrm{a}$ & $2.2 \mathrm{ab}$ \\
\hline & & $94.6 \mathrm{ABA}$ & $0.0 \mathrm{a}$ & $4.0 \mathrm{a}$ & $0.4 \mathrm{ab}$ \\
\hline & 6 & - & $0.0 \mathrm{a}$ & $12.0 \mathrm{a}$ & $1.8 \mathrm{ab}$ \\
\hline & & $0.5 \mathrm{BAP}$ & $32.0 \mathrm{abcd}$ & $18.0 \mathrm{ab}$ & $5.8 \mathrm{abcd}$ \\
\hline & & $18.9 \mathrm{ABA}$ & $4.0 \mathrm{a}$ & $8.0 \mathrm{a}$ & $1.8 \mathrm{ab}$ \\
\hline & & $94.6 \mathrm{ABA}$ & $0.0 \mathrm{a}$ & $0.0 \mathrm{a}$ & $0.0 \mathrm{a}$ \\
\hline
\end{tabular}

*Mean values followed by the same letters in columns do not differ at the significance level of $P \leq 0.05$ 
Figure 3 Effect of medium composition and time on the formation of bulbs from callus obtained from seedling-derived bulbs.

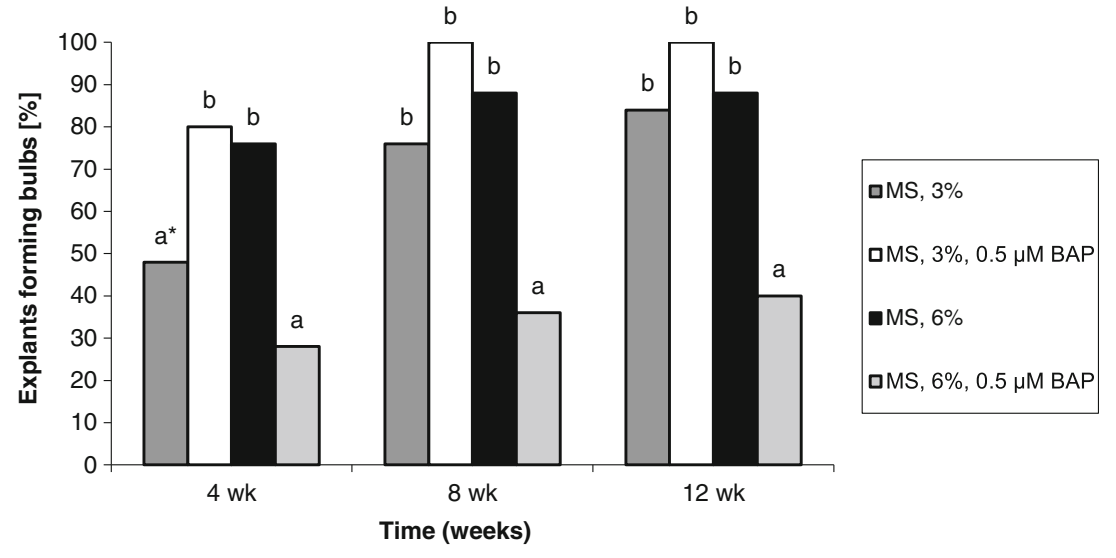

chilled adventitious bulbs treated with BAP. The formation of callus from non-chilled adventitious bulbs was more frequent (76 and $96 \%$ of explants) than from chilled adventitious bulbs (32 and $38 \%$ of explants) (Table 5).

For all explants and treatment combinations, the most frequent induction of adventitious bulbs was observed from explants derived from seedlings, although the differences between the mean values were not always significant. The induction of adventitious bulbs on the media containing $6 \%$ sucrose (alone or in combination with BAP) was significantly reduced as a result of chilling the explants beforehand. For the other combinations of culture media, there were no significant differences caused by chilling of the explants in the frequencies of bulb formation (Table 5). The number of bulbs per replicate was higher (although not always significantly) from explants cultured on treatments that cause higher-frequency callus formation.

Explants cultured with $6 \%$ sucrose (alone or in combination with BAP) formed several times fewer adventitious bulbs in comparison with non-chilled explants. Similar results were observed when explants were cultured with 3\% sucrose, mainly for explants derived from the bulbs that developed from seedlings. There were no significant differences among treatments for explants treated with ABA in the number of bulbs obtained (06 bulbs) (Table 5).

Frequencies of adventitious bulb formation. Because of the higher frequencies of callus formation from explants derived from non-chilled bulbs treated with sucrose and BAP, these subsequent experiments were restricted to only two types of explants and four culture media.

The percentage of explants forming adventitious bulbs gradually increased with increased length of culture. Bulb formation from seedling-derived callus tissue was promoted by the enrichment of the medium with $3 \%$ sucrose in conjunction with $0.5 \mu \mathrm{M}$ BAP or with $6 \%$ sucrose alone. As a result, after $12 \mathrm{wk}$, the percentage of explants forming adventitious bulbs was $84-100 \%$. Treatment with BAP and $6 \%$ sucrose significantly reduced (by more than half) the formation of adventitious bulbs (Fig. 3). For callus originating from adventitious bulbs, the highest percentage of explants form bulbs (84-88\%) when treated with 3\% and BAP. Means for other treatments ranged from 8 to $52 \%$ (Fig. 4 ).

For both types of explants, more bulbs formed on the media containing 3\% sucrose and $0.5 \mu \mathrm{M}$ BAP. Consequently, after $12 \mathrm{wk}, 42.8$ bulbs were obtained from callus originating from seedling-derived bulbs (Fig. 5) and 29.4 bulbs from the callus
Figure 4 Effect of medium composition and time on the formation of bulbs from callus obtained from adventitious bulbs.

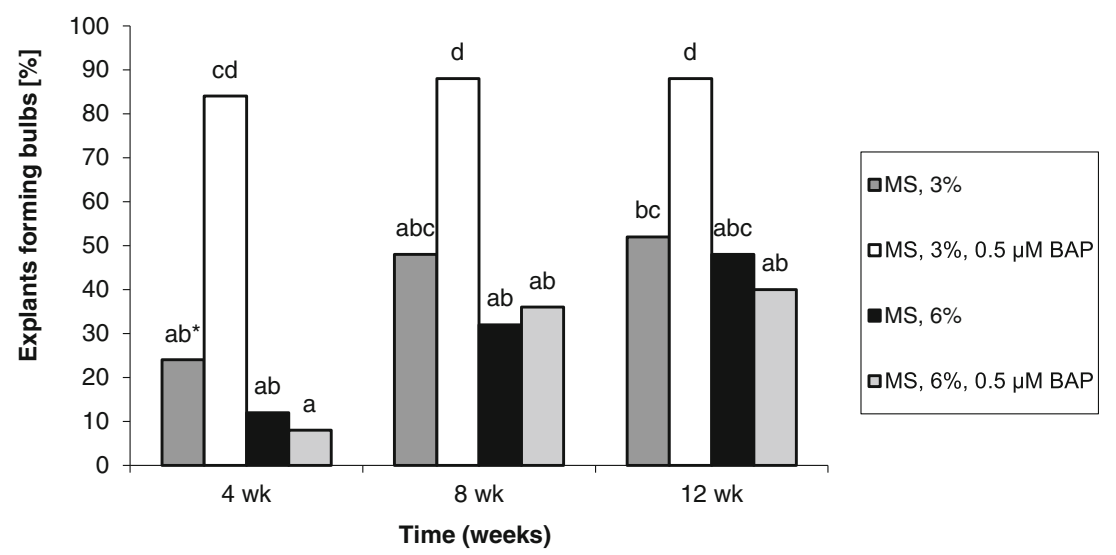


Figure 5 Effect of medium composition and time on the number of bulbs formed from callus obtained from seedlingderived bulbs.

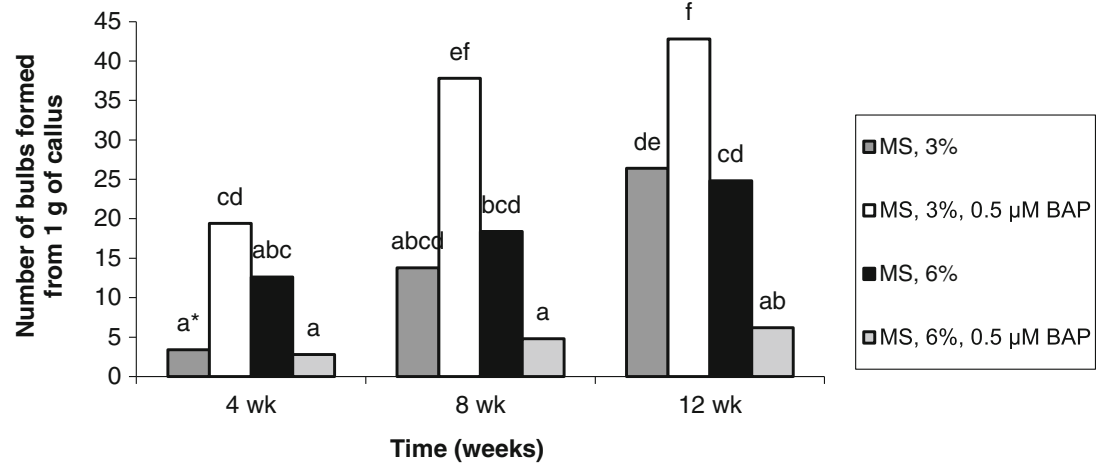

derived from adventitious bulbs (Fig. 6). The higher concentration of sucrose had a negative effect on the formation of bulbs in the case of callus derived from adventitious bulbs. Treatment with $6 \%$ sucrose resulted in the formation of 11.2 bulbs, and treatment with $6 \%$ sucrose and BAP resulted in the formation of 4.4 bulbs (Fig. 6).

Frequencies of callus tissue formation. The frequencies of callus formation from both types of explants gradually decreased over the culture period, although for treatments containing $6 \%$ sucrose, the frequency increased slightly in the last period (Figs. 7 and 8). The highest multiplication of callus (RGR $>1.2$ ), regardless of the explant source, took place in the first month on medium containing 3\% sucrose and $0.5 \mu \mathrm{M}$ BAP (Figs. 7 and 8).

Anatomical observations. Adventitious bulbs obtained in the experiments had a meristem (Fig. $2 g, h$ ), which indicated that they had developed properly. The absence of a covering scale, which protects the bulb from desiccation, was probably due to high relative humidity in the Petri dish.

\section{Discussion}

This study focused on the initial stages of T. tarda propagation in vitro. In vitro cultures of tulip are usually initiated from bulb scales (Nishiuchi 1980; Gude and Dijkema 1997), flower stems (Rice et al. 1983; Hulscher et al. 1992; Podwyszyńska and Marasek 2003) or ovaries (Ptak and Bach 2007). However, in the present study, cultures of T. tarda were initiated from seeds. Although using such explants was a more laborious and time-consuming, it was chosen to obtain more consistent and reliable starting material bulbs. Lowtemperature seed treatment, used in this study, is required not only for proper growth and flowering (Rietveld et al. 2000), but also to break dormancy after sowing (Fortanier and Van Brenk 1975; Rouhi et al. 2010). The zygotic embryo in tulip seeds does not have a fully developed apical bud and thus needs to be chilled to break its dormancy and initiate further development (Niimi 1978). The chilling of seeds can promote germination in T. tarda. Gibberellic acid (GA) (Kudryavtseva 1980; Rouhi et al. 2010) can also be applied during cold stratification to break seed dormancy in Tulipa kaufmanniana. Famelaer et al. (2000) reported that coldtreated $\left(4^{\circ} \mathrm{C}\right)$ seeds (embryos) were the most suitable explants for callus induction and proliferation of Tulipa praestans.

According to De Hertogh and Le Nard (1993), germination begins within a few days of seed hydration, as also confirmed with T. kaufmanniana (Rouhi et al. 2010). Cold-treated seeds of Tulipa gesneriana germinated after 5-6 wk (Famelaer et al. 1996). In this study, germination was not observed until 6 mo, as in nature. Nikolaeva (1977) claimed that T. tarda, apart from morphological dormancy, also underwent deep physiological dormancy, which explained its slow germination process. Furthermore, the germination of T. tarda took place under a 16-h photoperiod, while Custers and others (1992)
Figure 6 Effect of medium composition and time on the number of bulbs formed from callus obtained from adventitious bulbs.

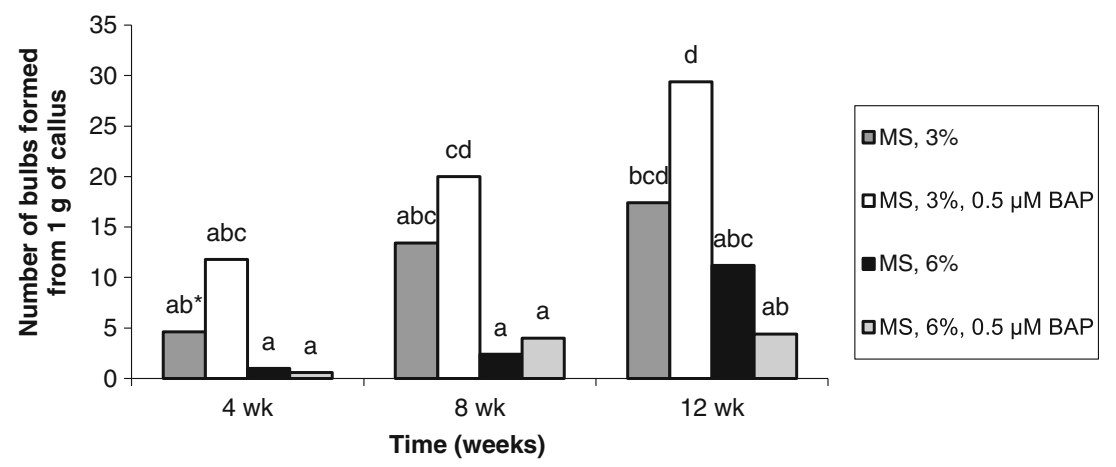


Figure 7 Effect of medium composition and time on the multiplication of callus obtained from seedling-derived bulbs.

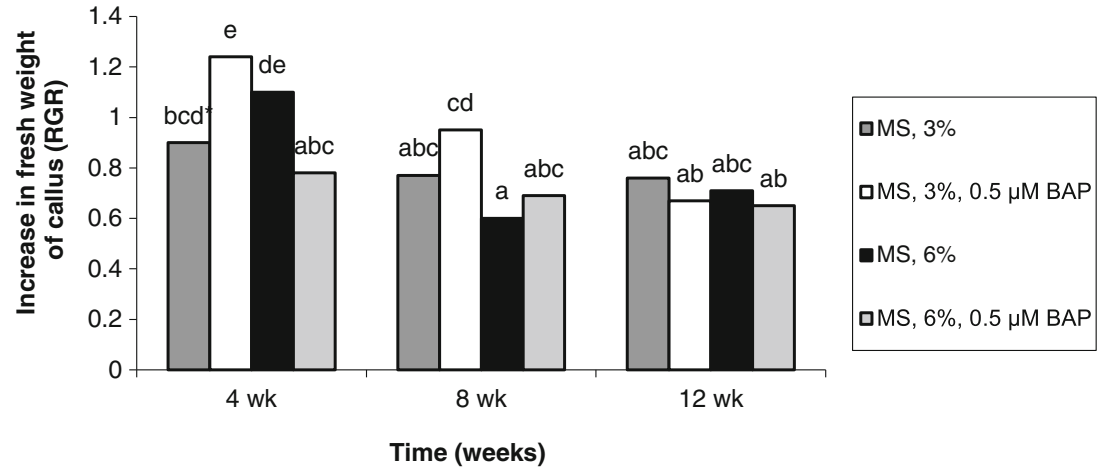

observed that darkness was superior to 16-h light in producing stolons and bulblets during the formation of tulip seedlings.

The highest frequency of germination was observed from seeds cultured on $100 \%$ MS with $3 \%$ sucrose at $25^{\circ} \mathrm{C}$. However, Boeken and Gutterman (1990) observed that Tulipa systola did not germinate at $25^{\circ} \mathrm{C}$ and germinated at $50 \%$ at $20^{\circ} \mathrm{C}$. In Lilium martagon, the best germination rate was obtained from seeds cultured on media containing $50 \%$ MS with $1.5 \%$ sucrose at $20^{\circ} \mathrm{C}$ (Kędra and Bach 2005). Thus, optimum conditions for seed germination are different for various plants, even among the same genus.

The explants used in this research originated from bulbs derived from seedlings or from adventitious bulbs produced from callus tissue. There is lack of reports concerning such tulip explants, which is why we examined their utility for T. tarda propagation. Seedling-derived bulbs and adventitious bulblets were the most useful explants for callus initiation in L. martagon (Kędra and Bach 2005).

The morphogenic response of the explants depends on the presence and concentration of growth regulators in the medium (Gaspar et al. 2003). To initiate organogenesis in tulips, BAP is usually used, either alone or with auxin (Wright and Alderson 1980; Taeb and Alderson 1990; Minas 2007), although Famelaer et al. (1996) used only picloram and 2,4dichlorophenoxyacetic acid (2,4-D) to obtain callus tissue. In this study, only $0.5 \mu \mathrm{M}$ BAP was used to stimulate organogenesis. Explants treated with BAP usually formed undifferentiated, yellowish, loose callus tissue, from which small bulbs differentiated. Higher frequencies of callus formation were observed when explants were treated with sucrose, with or without BAP. Similarly, the induction of callus in bulblet scale cultures of wild growing L. martagon was stimulated by both $0.5 \mu \mathrm{M}$ BAP and a growth regulator-free MS medium (Kędra and Bach 2005). In an experiment with 'Apeldoorn' tulips, bulb scale explants placed on an MS medium containing 2,4-D and kinetin also first produced callus and then organised structures (Baker et al. 1990). In bulblet scale cultures of Lilium ledebourii, the best media for adventitious bulblet formation contained $0.44 \mu \mathrm{M}$ BAP with $0.54 \mu \mathrm{M}$ naphthaleneacetic acid (NAA) (Bakhshaie et al. 2010). BAP with NAA was also used to form callus on scale explants in Fritillaria imperialis cultures (Witomska and Łukaszewska 1997). In bulb scale culture of Muscari azureum, the highest number of bulblets was obtained when treated with $0.5 \mu \mathrm{M}$ BAP, together with 2,4-D and NAA (Uranbey et al. 2010).

In this study, adventitious bulbs appeared on the explants via direct or indirect (via callus tissue) organogenesis. In previous experiments, tulip bulbs had been obtained mainly from shoots that regenerated on initial explants (Rice et al. 1983; Bach and Ptak 2005). Ghaffor et al. (2004) observed the formation of adventitious tulip bulblets from embryogenic cultures treated with BAP and NAA. Direct in vitro organogenesis of bulblets, on an MS medium supplemented with NAA and BAP, was observed in the case of Allium aflatunense (Evenor et al. 1997) and L. ledebourii (Bakhshaie et al. 2010).

Induction of tulip bulbs can occur in darkness, at $5^{\circ} \mathrm{C}$ over a 10-12-wk period (Baker et al. 1990; Kuijpers and Langens-
Figure 8 Effect of medium composition and time on the multiplication of callus obtained from adventitious bulbs.

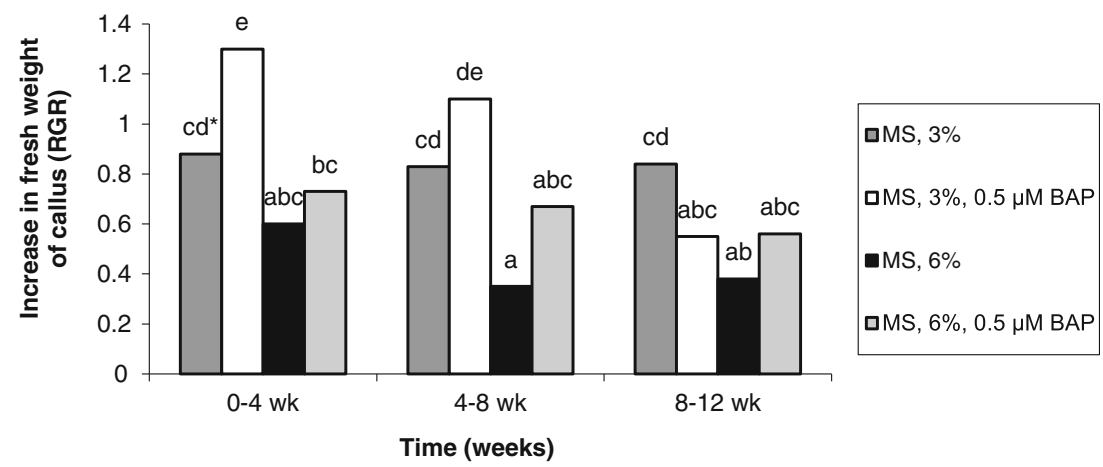


Gerrits 1997) when explants were cultured on an MS medium supplemented with 6\% sucrose (Alderson and Taeb 1990; Famelaer et al. 1996). Our results demonstrate that chilling explants decrease the formation of callus and bulbs. The addition of $6 \%$ sucrose did not enhance, but sometimes even reduced, the number of bulblets obtained. Generally, the bulblets were forming on media containing $3 \%$ sucrose and $0.5 \mu \mathrm{M}$ BAP in the dark.

In this study, the obtained bulbs did not have a tunic, perhaps because of the high relative humidity in the Petri dish. Such bulbs are vulnerable to drying out during cultivation $e x$ vitro. In their experiment, Podwyszyńska and Ross (2003) also observed tulip bulbs without a tunic, or only partially covered.

ABA affects tissue development and maturation through regulation of gene expression during vegetative development of plants (Boonekamp 1997; Seo and Koshiba 2002). ABA stimulates the formation of bulbs (Kuijpers and LangensGerrits 1997) in hyacinth (Ii et al. 2002), lily (Kim et al. 1994) and garlic (Kim et al. 2003). The effects of ABA on the formation of tulip bulbs are less clear. Podwyszyńska and Ross (2003) claimed that ABA has an adverse effect upon tulip bulb formation, which we also observed. The formation of callus and bulblets on every explant was inhibited by ABA, particularly at higher concentrations. Similar conclusions have been drawn for gloriosa lily (Weryszko-Chmielewska and Kozak 2002).

Histological analyses of the obtained bulbs revealed the occurrence of bulb scales and meristem in the middle, which suggests proper bulb development. Famelaer et al. (1996) also observed a bulb-like structure with one or two smaller leaves and small centers of densely cytoplasmic cells at the base side of the bulblet. The formation of bulbs determines the efficiency of the micropropagation of tulip (Hulscher et al. 1992).

Based on our results, bulbs from seedlings and adventitious bulbs were suitable explants for propagating T. tarda. The process of adventitious bulb formation was promoted by sucrose and BAP and inhibited by ABA and chilling. Although there is still a need to further investigate culture conditions to enhance tulip proliferation and bulblet formation, our results demonstrate that the procedure presented in this report can be used for the multiplication of T. tarda.

Acknowledgement This study was financed by Polish Ministry of Science and Higher Education, within the project "The use of biotechnological methods in intensifying the production of selected ornamental plants" (no. 3500/KRO/2009).

Open Access This article is distributed under the terms of the Creative Commons Attribution License which permits any use, distribution, and reproduction in any medium, provided the original author(s) and the source are credited.

\section{References}

Alderson PG, Taeb AG (1990) Influence of culture environment on shoot growth and bulbing of tulip in vitro. Acta Hortic 266:91-94

Bach A, Ptak A (2005) Induction and growth of tulip 'Apeldoorn' bulblets from embryo cultures in liquid media. In: Hvoslef-Eide AK, Preil W (eds) Liquid systems for in vitro plant propagation. Springer, The Netherlands, pp 359-364

Baker CM, Wilkins HF, Ascher PD (1990) Comparisons of precultural treatments and cultural conditions on in vitro response of tulip. Acta Hortic 266:83-90

Bakhshaie M, Babalar M, Mirmasoumi M, Khalighi A (2010) Somatic embryogenesis and plant regeneration of Lilium ledebourii (Baker) Boiss., an endangered species. Plant Cell Tiss Org Cult 102:229 235

Boeken B, Gutterman Y (1990) The effect of temperature on seed germination in three common bulbous plants of different habitats in the central Negev Desert of Israel. J Arid Environ 18:175-184

Boonekamp PM (1997) The role of external factors in growth and development of flower bulbs and bulb-flowers: an update since 1992. Acta Hortic 430:35-43

Botschantzeva ZP (1982) Tulips. Taxonomy, morphology, cytology, phytogeography and physiology. A. A. Balkema, Rotterdam

Custers JBM, Eikelboom W, Bergervoet JHW, Eijk JP (1992) In ovulo embryo culture of tulip (Tulipa L.): effects of culture conditions on seedling and bulblet formation. Sci Hortic 51:111-122

Custers JBM, Ennik E, Eikelboom W, Dons JJM, van Lookeren Campagne MM (1997) Embryogenesis from isolated microspores of tulip: towards developing F1 hybrid varieties. Acta Hortic 430: 259-266

De Hertogh A, Le Nard M (1993) The physiology of flower bulbs. Elsevier Science Publishers, The Netherlands, pp 612-682

Eijk JP, Raamsdonk LWD, Eikelboom W, Bino RJ (1991) Interspecific crosses between Tulipa gesneriana cultivars and wild Tulipa species: a survey. Sex Plant Reprod 4:1-5

Evenor D, Levi-Nissim A, Afgin L, Lilien-Kipnis H, Watad AA (1997) Regeneration of plantlets and bulblets from explants and callus of Allium aflatunense cultivars and selection from indigenous Israeli Allium ampeloprasum. Acta Hortic 430:325-330

Famelaer I, Ennik E, Creemers-Molenaar J, Eikelboom W, van Tuyl JM (2000) Initiation and establishment of long-lived callus and suspension cultures of Tulipa praestans. Acta Hortic 508:247252

Famelaer I, Ennik E, Eikelboom W, Van Tuyl JM, Creemers-Molenaar J (1996) The initiation of callus and regeneration from callus culture of Tulipa gesneriana. Plant Cell Tiss Org Cult 47:51-58

Fortanier EJ, Van Brenk G (1975) Dormancy of seeds as compared with dormancy of bulbs in tulips. Acta Hortic 47:331-338

Gaspar T, Kevers C, Faivre-Rampant O, Crevecoeur M, Cl P, Greppin H, Dommes J (2003) Changing concepts in plant hormone action. In Vitro Cell Dev Biol - Plant 39:85-106

Gerlach D (1969) Botanische Mikrotechnik. Eine Einführung. Georg Thieme Verlag, Stuttgart, pp 37-128

Ghaffor A, Maqbool I, Waseem K, Quraishi A (2004) In vitro response of tulips (Tulipa gesnerina L.) to various growth regulators. Short communication. Int J Agr Biol 6:1168-1169

Gude H, Dijkema MHGE (1997) Somatic embryogenesis in tulip. Acta Hortic 430:275-280

Hulscher M, Krijgsheld HT, Van der Linde PG (1992) Propagation of shoots and bulb growth of tulip in vitro. Acta Hortic 325:441-446

Ii K, Okubo H, Matsumoto T (2002) Control of bulb dormancy in hyacinth - a molecular biological approach. Acta Hortic 570:241-245

Jensen WA (1962) Botanical histochemistry. Freeman, San Francisco

Kędra M, Bach A (2005) Morphogenesis of Lilium martagon L. explants in callus culture. Acta Biol Cracov Ser Bot 47:65-73 
Kim EK, Hahn EJ, Murthy HN, Paek KY (2003) High frequency of shoot multiplication and bulblet formation of garlic in liquid cultures. Plant Cell Tiss Org Cult 73:231-236

Kim KS, Davelaar E, De Klerk GJ (1994) Abscisic acid controls dormancy development and bulb formation in lily plantlets regenerated in vitro. Physiol Plant 90:59-64

Kudryavtseva VM (1980) Germination of tulip seeds receiving different pre-sowing treatments. Byulleten' Glavnogo Botanicheskogo Sada 117:90-93

Kuijpers AM, Langens-Gerrits M (1997) Propagation of tulip in vitro. Acta Hortic 430:321-324

Maślanka M, Bach A (2010) The effect of abscisic acid, ethylene and inhibitors of their biosynthesis (Fluridone and salicylic acid) on somatic embryos conversion in tulips. Ecol Chem Eng S 17:1135-1139

Minas GJ (2007) In vitro propagation of Akama Tulip via adventitious organogenesis from bulb slices. Acta Hortic 755:313-316

Murashige T, Skoog F (1962) A revised medium for rapid growth and bioassays with tobacco tissue culture. Physiol Plant 15:473-497

Niimi Y (1978) Influence of low and high temperatures on the initiation and the development of a bulb primordium in isolated tulip embryos. Sci Hortic 9:61-69

Nikolaeva MG (1977) Factors controlling the seed dormancy pattern. In: Kahn AA (ed) The physiology and biochemistry of seed dormancy and germination. North-Holland, Amsterdam, pp 51-74

Nishiuchi Y (1980) Studies on vegetative propoagation of tulip. 4. Regeneration of bulblets in bulb scale segments cultured in vitro. $\mathrm{J}$ Jpn Soc Hortic Sci 49:235-239

Podwyszyńska M, Marasek A (2003) Effects of thidiazuron and paclobutrazol on regeneration potential of tulip flower stalk explants in vitro and subsequent shoot multiplication. Acta Soc Bot Pol 72: 181-190

Podwyszyńska M, Ross H (2003) Formation of tulips bulbs in vitro. Acta Hortic 616:413-417

Ptak A, Bach A (2007) Somatic embryogenesis in tulip (Tulipa gesneriana L.) flower stem cultures. In Vitro Cell Dev Biol - Plant 43:35-39
Rees AR (1992) Propagation ornamental bulbs, corms and tubers. CAB, Wallingford, pp 93-111

Rees AR, Hanks GR (1979) Potential uses of plant growth regulators in bulb growing and forcing. Acta Hortic 91:153-159

Rice RD, Alderson PG, Wright NA (1983) Induction of bulbing of tulip shoots in vitro. Sci Hortic 20:377-390

Rietveld PL, Wilkinson C, Franssen HM, Balk PA, Plas LHW, Weisbeek PJ, Boer AD (2000) Low temperature sensing in tulip (Tulipa gesneriana L.) is mediated through an increased response to auxin. J Exp Bot 344:587-594

Rouhi HR, Shakarami K, Tavakkol Afshari R (2010) Seed treatments to overcome dormancy of waterlily tulip (Tulipa kaufmanniana Regel.). Aust J Crop Sci 4:718-721

Seo M, Koshiba T (2002) Complex regulation of ABA biosynthesis in plants. Trends Plant Sci 1:41-48

Taeb AG, Alderson PG (1990) Shoot production and bulbing of tulip in vitro related to ethylene. J Hortic Sci 2:199-204

Taghi ZM, Babalar M, Zamani ZA, Naderi R, Askari MA (2007) Direct and indirect regeneration of adventitious shoots in ornamental Tulipa gesneriana L. 'Apeldoorn' by using in vitro culture method. Iran J Agr Sci 37:1031-1039

Uranbey S, Ipek A, Caliskan M, Dundar E, Cocu S, Basalma D, Guneylioglu H (2010) In Vitro bulblet induction from bulb scales of endangered ornamental plant Muscari azureum. Biotechnol Biotech Eq 24:1843-1848

Weryszko-Chmielewska E, Kozak D (2002) Anatomical changes in Gloriosa rothschildiana O'Brien stems induced by JA-Me and ABA. Acta Hortic 570:433-436

Wilmink A, Van de Ven BCE, Custers JBM, Nöllen Y, Dons JJM (1995) Adventitious shoot formation in tulip: histological analysis and response to selective agents. Plant Sci 110:155-164

Witomska M, Łukaszewska AJ (1997) Bulblet regeneration in vitro from different explants of Fritillaria imperialis. Acta Hortic 430: 331-335

Wright NA, Alderson PG (1980) The growth of tulip tissues in vitro. Acta Hortic 109:263-270 